\title{
Model Komunikasi Pemasaran Terpadu Sport Tourism di Kabupaten Malang
}

\author{
Gabriella Sagita Putri ${ }^{1}$, Adhi Murti Citra Amalia ${ }^{2}$ \\ 1,2 Public Relations Department, Faculty of Economics \& Communication, Bina \\ Nusantara University \\ Email: 1gabriella.putri004@binus.ac.id,2adhimurti.amalia@binus.ac.id
}

\section{How to Cite This Article:}

Putri, G. S., \& Amalia, A. M. C. (2020). Model Komunikasi Pemasaran Terpadu Sport Tourism di Kabupaten Malang. Expose: Jurnal Ilmu Komunikasi, 3(1), 1-20. DOI: 10.33021/exp.v3i1.968.
Received: 24-02-2020

Revision: 18-04-2020

Acceptance: $10-05-2020$

Published online: 12-05-2020

English Title: Integrated Marketing Communication Model for Sport Tourism in Kabupaten Malang

\begin{abstract}
Beach is one of the favorite tourism attraction in Kabupaten Malang which locate at the south area of Kabupaten Malang. The most potentials beach's character in Kabupaten Malang is a sport tourism which combines seaside view and water sport activities, such as surfing, beach running, and paragliding. Sport tourism is a concept should be one of destination branding strategy to strengthening brand image of tourism object in Kabupaten Malang. The purpose of this paper is to identify integrated marketing communication model to developing sport tourism promotion in Kabupaten Malang. This is a qualitative paper in which informant are determined purposively, they are Head of Dinas Pariwisata dan Kebudayaan, and Section Head of Tourism Promotion and Cooperation Kabupaten Malang. Research finding explained that sport tourism can be developed as a destination branding for beach tourism in Kabupaten Malang, such as pantai Nganteb, pantai Modangan, and pantai Lenggoksono. Communication model to improving sport tourism in Malang can use public relations approach to strengthen relationship among relate stakeholders. Digital media can also used as integrated marketing communication model due to the most accessible communication channel. Virtual interaction with public should improve marketing communication performance.
\end{abstract}

Keywords: Marketing communication, destination branding, sport tourism 


\begin{abstract}
Abstrak Pantai merupakan salah satu objek wisata unggulan di Kabupaten Malang yang berada di wilayah Malang Selatan. Salah satu potensi yang dimiliki dari karakter pantai di Kabupaten Malang adalah sport tourism yang memadukan wisata pantai dengan kegiatan olahraga bahari, seperti olahraga selancar, paralayang, dan lari pantai. Konsep sport tourism diharapkan sebagai strategi destinasi branding yang mampu meningkatkan brand image objek wisata pantai di Kabupaten Malang. Tujuan penelitian ini adalah mengidentifikasi model komunikasi pemasaran terpadu yang tepat sebagai strategi pengembangan sport tourism di Kabupaten Malang. Penelitian ini merupakan penelitian kualitatif dengan informan penelitian yang ditentukan secara purposif, yaitu Kepala Dinas Pariwisata dan Kebudayaan, serta Kepala Seksi Promosi dan Kerjasama Pariwisata Kabupaten Malang. Hasil penelitian menunjukan bahwa sport tourism dapat dikembangan sebagai destinasi branding objek wisata pantai di Kabupaten Malang, seperti pantai Nganteb, pantai Modangan, dan pantai Lenggoksono. Model komunikasi untuk mengembangkan destinasi wisata sport tourism di Kabupaten Malang menggunakan pendekatan public relations untuk memperkuat kerjasama antara pengelola destinasi wisata dengan media, publik, dan organisasi terkait sebagai stakeholder. Pendekatan media digital juga digunakan sebagai model komunikasi pemasaran karena media digital sebagai saluran komunikasi yang paling mudah diakses masyarakat. Interaksi dengan pelanggan secara digital tersebut diharapkan dapat meningkatkan kinerja komunikasi pemasaran.
\end{abstract}

Kata Kunci: Komunikasi pemasaran, destinasi branding, sport tourism

\title{
PENDAHULUAN
}

Sport tourism sebagai konsep dalam pengembangan industri wisata di Indonesia mengalami pertumbuhan yang cepat, yakni enam persen (6\%) per tahun atau sekitar 600 miliar dolar per tahun. Selain itu, 25\% dari total penerimaan industri perjalanan dan pariwisata berasal dari aktivitas sport tourism (Amazia 2019). Menurut I Gde Pita, Deputi Pengembangan Pemasaran I Kementerian Pariwisata dan Ekonomi Kreatif, saat ini yang dibutuhkan diversifikasi, perluasan dan penguatan daya tarik wisata atau event wisata olahraga bertaraf internasional untuk meningkatkan potensi sport tourism di Indonesia. Menteri Pariwisata pada periode tahun 2014-2019, Arief Yahya juga menjelaskan bahwa media value dari event sport tourism besarnya dua kali lipat dari direct impact. Beberapa sport tourism yang diselenggarakan di Indonesia dari skala regional sampai internasional, contohnya Tour de Singkarak, Tour de Flores, Tour de Ijen, Borobudur Marathon, Jogja Marathon Festival, dan sebagainya. 
Sport tourism merupakan suatu konsep tentang kegiatan wisata yang dipadukan kegiatan olahraga, atau dapat didefinisikan aktivitas olahraga yang bertujuan sebagai strategi promosi pariwisata suatu daerah. Dengan adanya event olahraga dalam skala besar diharapkan objek wisata yang dijadikan spot olahraga juga semakin dikenal publik, sehingga roda perekonomian di sekitar daerah wisata juga turut bergerak. Seperti yang dilansir dari kontan.co.id (19/11/18), ada dua jenis sport tourism yaitu, hard sport tourism yang merupakan kompetisi olahraga yang diselenggarakan secara regular seperti Asian Games, Sea Games, Olimpiade, dan World Cup. Ada juga soft sport tourism merupakan aktivitas olahraga yang berkaitan dengan unsur life style seperti lari, bersepada, selancar, diving, rafting dan sebagainya. Untuk mendukung pengembangan event sport tourism diperlukan dukungan dari sisi pemasaran terutama untuk kegiatan promosi. Unsur wilayah tempat diselenggarakannya event sport tourism juga tentu menjadi faktor utama dalam mengembangkan konsep sport tourism, terutama wilayah pantai yang sangat berpotensi sebagai spot wisata olahraga bahari. Indonesia memiliki beberapa wilayah pantai dari ujung barat sampai wilayah timur dengan kondisi alam dan ombak yang cocok untuk spot olahraga air.

Kota wisata seribu pantai merupakan julukan bagi kabupaten Malang yang terkenal karena daerah ini memiliki banyak objek wisata pantai yang terbentang dengan garis pantai sepanjang 102,5 km dihitung dari sepanjang pantai selatan Jawa mulai dari Pantai Modangan, kecamatan Donomulyo sampai pantai Licin, kecamatan Ampelgading, Malang Selatan. Berdasarkan data yang diperoleh dari Dinas Pariwisata dan Kebudayaan Kabupaten Malang bahwa terdapat 101 objek wisata pantai yang masuk di area kabupaten Malang. Dengan jumlah pantai yang banyak dan luas wilayah pantai yang mencapai $102,5 \mathrm{~km}$ sangat berpotensi memberi sumbangan yang berarti bagi peningkatan pendapatan dan kesejahteraan masyarakat setempat. Sektor pariwisata menjadi salah satu prioritas program pembangunan ekonomi daerah di Kabupaten Malang, seperti yang disampaikan oleh Kepala Dinas Pariwisata dan Kebudayaan Kabupaten Malang Made Arya Wedanthara bahwa pemerintah daerah mentargetkan angka kunjungan wisata yang meningkat dari tahun 2018. Pada tahun 2018 target tujuh juta kunjungan wisatawan tercapai, sehingga untuk tahun 2019 target dinaikan sebesar sepuluh persen. Selain target kunjungan wisata, pemerintah daerah 
melalui Dinas Pekerjaan Umum Kabupaten Malang juga fokus pada penyelesaian infrastruktur jalan wisata di Malang Selatan. Menurut Made bahwa Malang yang dikenal sebagai daerah seribu pantai seharusnya juga akan terus berhasil mendatangkan jumlah wisatawan yang signifikan dari beragam objek wisata pantai di Malang Selatan, namun beliau juga mengakui ada beberapa tugas besar pada objek wisata Pantai Malang Selatan untuk menghadirkan image positif pantai Malang Selatan kepada publik.

Pengembangan objek wisata pantai di Malang Selatan dengan berbasis pada konsep sport tourism menjadi salah satu alternatif strategi destinasi branding yang dilakukan oleh pemerintah daerah kabupaten Malang. Setelah pemerintah Kabupaten Malang meluncurkan 'Heart of East Java' sebagai semboyan branding Kabupaten Malang, Pemerintah daerah kabupaten Malang melalui Dinas Pariwisata dan Kebudayaan setempat mulai mengembangkan strategi pemasaran objek wisata dengan mengadakan beberapa event rutin di objek wisata tersebut. Kabupaten Malang memiliki satu event tahunan diadakan menjelang hari jadi Kabupaten Malang yaitu Malang Beach Festival yang didalamnya ada beberapa acara dan perlombaan seperti Festival Layang-layang, Voli Pantai, Paralayang, Singhasari Surfing International, Nganteb on Stage Music Festival, Jetski and Skateboard Exhibition yang mana seluruh acara tersebut berpusat di pantai selatan Kabupaten Malang. Seluruh event tersebut diadakan di pantai selatan Kabupaten Malang dengan harapan mampu meningkatkan promosi dan kunjungan wisata di Kabupaten Malang dan mengenalkan event besar kabupaten Malang kepada masyarakat dan wisatawan.

Menurut Moilanen dan Rainisto (2009) dalam buku How to Brand Nations, Cities, dan Destinations untuk menyusun strategi promosi sebuah negara, kota, dan kawasan wisata perlu standar pemasaran suatu produk, brand image yang dipercaya sebagai mesin penggerak untuk menghasilkan keuntungan secara ekonomis maupun non ekonomis. Image yang positif sangat diperlukan dalam upaya memperkenalkan potensi daerah melalui pengembangan objek wisata di suatu wilayah, sehingga dibutuhkan strategi destination branding untuk menciptakan kemudian memperkuat image yang positif bagi khalayak, dengan harapan dapat menarik minat khalayak untuk mengunjungi daerah wisata (Moilanen \& Rainisto, 2009). Court dan Lupton (1997) dalam hasil studinya menyatakan bahwa image suatu destinasi yang positif akan 
mempengaruhi niat untuk berkunjung lagi diwaktu yang akan datang dan meningkatkan loyalitas terhadap tujuan wisata (Court \& Lupton, 1997). Brand image yang kuat tentu perlu ditunjang oleh strategi komunikasi yang tepat menyampaikan pesan tentang suatu brand, sehingga khalayak dapat 'menangkap' pesan dari suatu destinasi wisata. Dalam komunikasi pemasaran, memiliki konsep 4P pemasaran yang terdiri dari product, place, price and promotion yang mana aspek promotion merupakan fokus yang dikaji dalam penelitian ini. Aspek promosi dapat ditentukan dari model komunikasi pemasaran terpadu yaitu bentuk integrasi dari semua alat komunikasi pemasaran untuk mengirim pesan yang jelas, konsisten dan meyakinkan yang berkenaan dengan perusahaan dan produknya (Kotler dan Amstrong, 2004). Berdasarkan definisi dan penjelasan tersebut, diperlukan model komunikasi pemasaran yang terintegrasi sebagai salah satu strategi untuk mempromosikan objek wisata pantai berbasis pada sport tourism di Kabupaten Malang. Penelitian ini akan mengembangkan suatu model komunikasi pemasaran terpadu untuk objek wisata pantai berbasis sport tourism. Fokus penelitian ini adalah bagaimana pengembangan model komunikasi pemasaran terpadu yang tepat sebagai bagian dari strategi promosi wisata pantai dengan konsep sport tourism di Kabupaten Malang.

\section{LANDASAN TEORI}

\section{Destination Branding}

Brand atau merek dapat didefinisikan sebagai nama, symbol atau identitas lainnya yang melekat pada suatu produk atau jasa, sedangkan branding merupakan proses pemberian identitas berupa nama, tanda, simbol, atau kombinasi dari semuanya yang dibuat dengan tujuan memberikan identitas barang atau jasa untuk membedakan dari barang atau jasa pesaing. Brand image adalah deskripsi yang terbentuk tentang asosiasi dan keyakinan terhadap brand tertentu.

Dalam konsep pemasaran objek wisata, brand dalam destinasi wisata diperlukan untuk menghadapi persaingan, terutama beberapa destinasi yang belum memiliki identitas kuat. Menurut Bungin (2015), brand suatu destinasi haruslah mencakup keseluruhan destinasi yang didalamnya terdapat nilai, filosofi, budaya, serta harapan masyarakat atau stakeholder di dalam destinasi tersebut (Bungin 2015). Dalam branding 
destinasi wisata yang menjadi tujuan utama adalah menciptakan value dan pengalaman berbeda bagi pengunjung destinasi wisata. Untuk menciptakan value, diperlukan strategi aktivasi dengan berbagai kegiatan promosi yang mampu meningkatkan brand awareness masyarakat.

Brand destinasi yang diciptakan perlu melewati tahap yang sulit dan panjang, sehingga destinasi tersebut akan memiliki kekuatan dari identitas destinasi wisata itu sendiri. Untuk menciptakan Brand Destinasi yang kuat, dapat mengacu pada aspekaspek kekuatan Brand Destinasi menurut Risitano berikut ini (Risitano, 2006) :

\section{Gambar 1. Kekuatan Brand Destinasi}

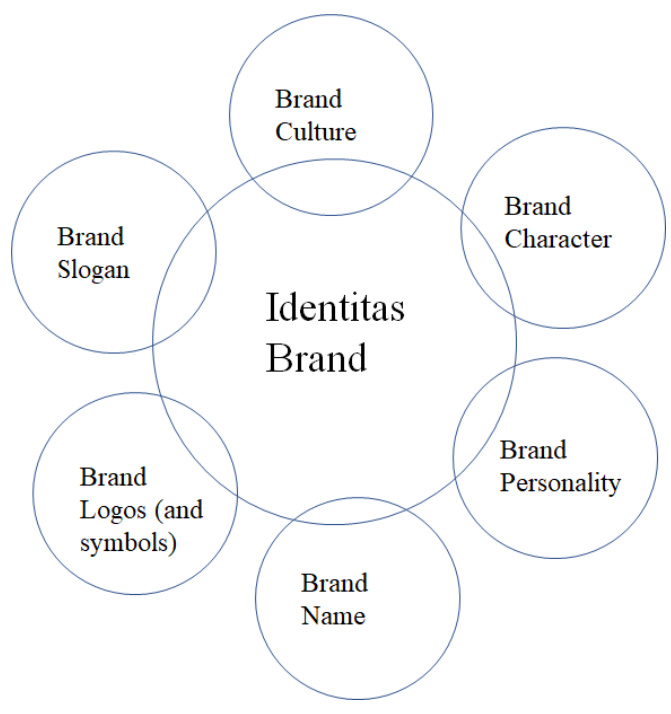

Sumber; (Risitano, 2006)

Brand culture merepresentasikan karakteristik destinasi berdasarkan aspek budaya masyarakat, seperti kepercayaan, tradisi, ritual, dan lain-lain, dan aspek destinasi itu sendiri, seperti situs bersejarah, monumen, situs arkeologi, bangunan tua. Brand character berhubungan dengan komitmen sebuah destinasi dalam memberikan pengalamannya, seperti integritas, kepercayaan, kejujuran. Brand Personality adalah bagaimana suatu destinasi membangun kepribadian yang tepat dan sesuai seperti kepribadian manusia dalam kehidupan sehari-hari; down-to-earth, ceria, senang berimajinasi, berkelas tinggi, suka berpetualang, dan lain sebagainya. Kemudian aspek berikutnya adalah brand name yang merupakan salah satu yang terpenting dalam penyusunan strategi komunikasi pemasaran, sehingga dalam menentukan brand name 
EXPOSE: Jurnal Ilmu Komunikasi

ISSN 2620-8105 | E-ISSN 2621-0304

Volume 03, No. 01, April, 2020

harus memiliki keunikan dan mudah diingat seperti Wonderful Indonesia, Incredible India, Imagine Your Korea, Malaysia Truly Asia, 100\% Pure New Zealand. Logo atau simbol juga harus mendefinisikan kekuatan dari sebuah brand destination. Aspek terakhir adalah Brand Slogan dibutuhkan dalam membangun brand destination untuk menyampaikan pesan brand secara lebih persuasif sehingga wisatawan menjadi tertarik untuk berkunjung. Berdasarkan enam aspek kekuatan destinasi branding, dapat disimpulkan bahwa destinasi brand yang ideal adalah brand yang mampu merepresentasikan nilai, budaya, filosofi, harapan masyarakat atau stakeholder di dalam suatu destinasi tentunya akan sangat berpengaruh positif terhadap perkembangan pariwisata di destinasi tersebut (Pandu 2018).

\section{Komunikasi Pemasaran Terpadu}

Komunikasi pemasaran terpadu (integrated marketing communication) merupakan konsep integrasi dan koordinasi berbagai saluran komunikasi untuk menyampaikan pesan yang jelas, konsisten, dan meyakinkan mengenai perusahaan dan produknya (Kotler and Armstrong 2017). Berdasarkan definisi dari konsep komunikasi pemasaran terpadu, dalam penelitian pengembangan model komunikasi pemasaran terpadu wisata pantai di Kabupaten Malang membutuhkan strategi promosi yang terkoordinasi sesuai dengan konsep sport tourism.

Kotler dan Ketler juga menjelaskan terkait tujuh elemen alat komunikasi pemasaran terpadu atau bauran promosi, diantaranya adalah;

- Iklan (advertising) merupakan segala bentuk pesan persuasi nonpribadi dan promosi gagasan, barang, atau jasa oleh sponsor tertentu yang harus dibayar.

- Public relations merupakan strategi yang ditujukan untuk merangsang minat yang positif terhadap perusahaan tertentu dan produk-produknya dengan mengirimkan berita baru melalui konferensi pers, melaksanakan acara-acara khusus, dan memberi sponsor aktivitas yang layak diliput oleh pihak ketiga.

- Promosi penjualan (sales promotion) adalah berbagai kumpulan alat-alat insentif yang sebagian besar berjangka pendek yang dirancang untuk 
EXPOSE: Jurnal Ilmu Komunikasi

ISSN 2620-8105 | E-ISSN 2621-0304

Volume 03, No. 01, April, 2020

merangsang pembelian produk atau jasa tertentu dengan lebih cepat dan lebih besar oleh konsumen atau pedagang.

- Penjualan personal (personal selling) adalah interaksi langsung antara penjual dan calon pembelinya, dengan tujuan membujuk calon pembeli untuk membeli produk atau jasa yang ditawarkan.

- Pemasaran langsung (direct marketing) adalah penggunaan beberapa media untuk berkomunikasi secara langsung dengan atau mendapat tanggapan langsung yang dirancang untuk meningkatkan kesadaran, memperbaiki citra, dan meningkatkan penjualan produk atau jasa.

- Event merupakan bentuk kegiatan dimana perusahaan memberikan sponsor pada kegiatan dan program-program yang dirancang untuk menciptakan interaksi setiap hari atau interaksi yang berkaitan dengan merek.

- Worth of mouth marketing adalah komunikasi lisan, tertulis dan elektronik antar individu atau kelompok yang berhubungan dengan pengalaman menggunakan produk atau jasa yang pernah digunakan.

Ketujuh elemen komunikasi pemasaran digunakan secara terpadu atau terintegrasi untuk mengkomunikasikan konsep sport tourism wisata pantai di Kabupaten Malang. Dalam menentukan elemen komunikasi yang tepat untuk menghasilkan model komunikasi terpadu, diperlukan beberapa tahap menentukan strategi promosi wisata pantai berbasis konsep sport tourism.

\section{METODE PENELITIAN}

Penelitian ini menggunakan pendekatan kualitatif dengan metode eksploratif. Metode eksploratif merupakan metode penelitian yang bertujuan untuk menggali dan mengekplorasi secara utuh sebab dan akibat, kemudian hal-hal yang mempengaruhi terjadinya sesuatu (Arikunto, 2005). Kotler menyatakan bahwa penelitian eksplorasi merupakan salah satu metode penelitian yang digunakan untuk meneliti sesuatu yang belum diketahui, belum dipahami, atau belum dikenali dengan baik. Dalam penelitian ini, peneliti melakukan pemetaan dari masing-masing elemen komunikasi pemasaran yang digunakan sebagai alat promosi sport tourism pantai di Kabupaten Malang. 
Dalam penelitian ini, data diperoleh dari sumber data primer dan sumber data sekunder. Data primer merupakan data yang diperoleh secara langsung dari sumber pertama (Siregar 2013). Proses pengumpulan data primer menggunakan teknik interview dengan pedoman wawancara yang telah disusun berdasakan permasalahan penelitian yang dikaji. Informan ditentukan secara purposif, yaitu pengambilan informan telah ditentukan untuk memperoleh data yang tepat. Informan dalam penelitian ini adalah Kepala Dinas Pariwisata dan Kebudayaan, serta Kepala Seksi Promosi dan Kerjasama Pariwisata Kabupaten Malang. Sedangkan data sekunder yang merupakan data untuk melengkapi data primer, dalam penelitian ini didapat dari berita, dokumen, informasi dari berbagai media serta data-data lain yang berkaitan dengan penelitian ini.

Uji keabsahan data menggunakan triangulasi data yaitu menggunakan berbagai sumber data seperti dokumen, hasil wawancara, hasil observasi atau dengan mewawancarai selain informan yang dianggap memiliki sudut pandang yang berbeda (Sulistianty, 1999). Dalam melakukan uji keabsahan, peneliti juga melakukan wawancara dengan komunitas Pokdarwis dan beberapa pengunjung pantai untuk melakukan konfirmasi atas jawaban informan kunci dalam penelitian ini.

\section{HASIL DAN PEMBAHASAN}

Berdasarkan hasil wawancara yang dilakukan, gambaran umum bahwa beberapa pantai di Kabupaten Malang memiliki karakteristik yang sangat ideal jika dikembangkan sebagai destinasi wisata yang mengusung konsep sport tourism. Ada dua pantai di Kabupaten Malang yaitu pantai Lenggoksono dan pantai Ngudel yang secara spesifik dikembangkan sebagai pusat sport tourism. Menurut kepala Bidang Pengembangan Daerah Wisata Kabupaten Malang menyatakan bahwa karakteristik pantai-pantai di Malang dinilai sangat ideal digunakan sebagai jantung wisata bahari karena sifatnya one stop tourism. Ada beberapa pantai yang memiliki pemandangan menarik jika dijadikan spot fotografi, sehingga banyak pengunjung selalu mengambil gambar dan mengunggah ke media sosial seperti pantai Goa Cina, pantai Tiga Warna, dan pantai Teluk Asmara. Ada juga wisata pantai yang dikembangkan sebagai pusat penyelenggaraan event tahunan seperti Malang Beach Festival yaitu pantai Ngliyep, pantai Nganteb, pantai Lenggoksono dan beberapa pantai sekitarnya. Dalam event 
tersebut diadakan berbagai aktivitas dan kompetisi olahraga bahari, seperti Festival Layang-layang, Voli Pantai, Selancar, dan Paralayang. Dengan adanya beberapa event olahraga yang diadakan di beberapa pantai kawasan Malang Selatan, memperkuat destinasi branding yang dilakukan oleh Pemerintah Kabupaten Malang terhadap kawasan pantai yang memiliki potensi sebagai obyek wisata dengan konsep sport tourism. Berdasarkan penelitian yang pernah dilakukan oleh Nur Muffdarunnisa (2014), membuat tipologi objek wisata di Malang berdasarkan kajian fasilitas primer (site attractions dan event attractions), pengembangan fasilitas sekunder dan fasilitas kondisional serta rata-rata jumlah kunjungan wisatawan setiap tahun (Nur Mufidatunnisa 2014). Dari hasil kajian tersebut teridentifikasi bahwa objek wisata pantai, seperti pantai Kondang Merak, pantai Nganteb dan pantai Goa Cina termasuk mendekati tipe allosentris meskipun belum terdapat event attractions karena aksesibilitas rendah, namun memiliki site attractions yang cukup baik. Dengan site attractions yang baik objek wisata pantai tersebut dapat dikembangkan melalui aktivitas adventure seperti berkemah, motor trail, offroad, outbond adventure yang sesuai dengan konsep sport tourism. Sedangkan tipologi berikutnya yaitu mid-sentris seperti pantai Balekambang, pantai Pasir Panjang, pantai Ngliyep, pantai Bajulmati dan pantai Sendang Biru yang tidak terdapat event attractions namun secara site attractions sangat beragam sehingga sangat mendukung aktivitas wisatawan berupa petualangan dengan berbagai fasilitas dan aksesibilitas yang tinggi. Aktivitas olahraga sangat cocok untuk menjadi strategi promosi melalui sport event. Water sport, menyelam, snorkling, memancing merupakan contoh aktivitas olahraga bahari yang dapat dikemas menjadi event untuk memperkuat sport tourism di kabupaten Malang.

Pengembangan destinasi wisata dengan konsep sport tourism sangat membutuhkan sarana promosi yang mampu menguatkan brand image wisata pantai. Dalam menentukan brand image destinasi, pengelola objek wisata perlu mengali identitas yang kuat dan memiliki ciri khas yang berbeda dengan objek wisata lainnya. Menurut Bungin (2015), brand suatu destinasi haruslah mencakup keseluruhan destinasi yang didalamnya terdapat nilai, filosofi, budaya, serta harapan masyarakat atau stakeholder di dalam destinasi tersebut (Bungin 2015), sehingga dalam melakukan destination branding yang menjadi fokus utama adalah bagaimana menciptakan value dan 
pengalaman berbeda bagi pengunjung destinasi wisata. Salah satu strategi untuk mengenalkan pantai di Malang yang berpotensi sebagai salah satu pusat sport tourism di Jawa adalah menggunakan strategi event. Menurut Kepala Seksi Promosi dan Kerjasama Pariwisata Kabupaten Malang, menyatakan bahwa tujuan dari pemilihan saluran promosi melalui event bukan menciptakan instant tourism yang hanya bertahan selama acara berlangsung, tetapi dapat menjadi stimulus yang positif bagi pengembangan ekonomi dan sumber daya manusia setempat. Event merupakan salah satu saluran komunikasi pemasaran yang dapat meningkatkan brand awareness wisatawan yang menjadi target pengunjung dari obyek wisata, sehingga melalui event diharapkan mampu menyedot perhatian dan meningkatkan kunjungan wisata dalam jumlah yang besar. Beach Vest merupakan salah satu event yang mampu mendatangkan para surfer lokal maupun mancanegara untuk mengikuti kompetisi surfing. Selain selancar, ada juga aktifitas paralayang dan marathon yang juga menarik untuk mendukung destinasi branding wisata pantai di Malang.

Sport tourism dapat memberikan dampak dalam peningkatan jumlah wisatawan ke destinasi pariwisata, hal ini berkaitan dengan strategi promosi dan pengenalan daerah tujuan wisata (Saputra and Harto 2016). Terkait dengan strategi promosi pengembangan destinasi wisata pantai melalui penyelenggaraan event olahraga, ada tiga lingkup yang perlu diperhatikan yaitu;

1. Manajemen event olahraga, yaitu pengelolaan berbagai hal terkait pelaksanaan aktivitas olahraga di objek wisata baik secara teknik maupun non teknis

2. Manajemen event promosi, yaitu pengelolaan berbagai hal yang terkait dengan upaya mempromosikan daerah tujuan wisata yang menjadi lokasi event olahraga.

3. Manajemen kegiatan pendukung, yaitu pengelolaan berbagai kegiatan yang berkontribusi penting dalam mendukung penyelenggaraan event.

Berdasarkan tiga lingkup tersebut, strategi event sebagai salah satu model komunikasi pemasaran yang tepat untuk mempromosikan sport tourism objek wisata pantai di Malang perlu skema konsep penyelenggaraan event berdasarkan tiga konsep diatas. 
Skema konsep penyelenggaraan Malang Beach Festival sebagai salah satu event sport tourism andalan kabupaten Malang merupakan contoh pengembangan tiga area utama yang mendukung implementasi promosi destinasi wisata sport tourism dengan saluran komunikasi event. Malang Beach Festival yang diagendakan setiap tahun merupakan hasil kerjasama antara Federasi Aero Sport Indonesia (FASI) dan Dinas Pariwisata dan Kebudayaan Kabupaten Malang adalah salah satu upaya menguatkan branding dan tagline pariwisata Kabupaten Malang, yakni sebagai jantungnya Jawa Timur (the heart of east Java) (Gumilang 2019). Jika dianalisa melalui tiga lingkup utama penyelenggaraan event dengan konsep sport tourism, dalam lingkup manajemen event olahraga koordinasi antara penyelenggara (Dinas Pariwisata dan Kebudayaan Kabupaten Malang) dengan stakeholder lainnya yaitu asosiasi cabang olahraga terkait sudah ada. Sedangkan pada lingkup manajemen event, adanya target peserta dalam Malang Beach Festival menjadi fokus utama dalam pengelolaan event.

\section{Gambar 2. Contoh Konsep Penyelenggaraan Malang Beach Festival}

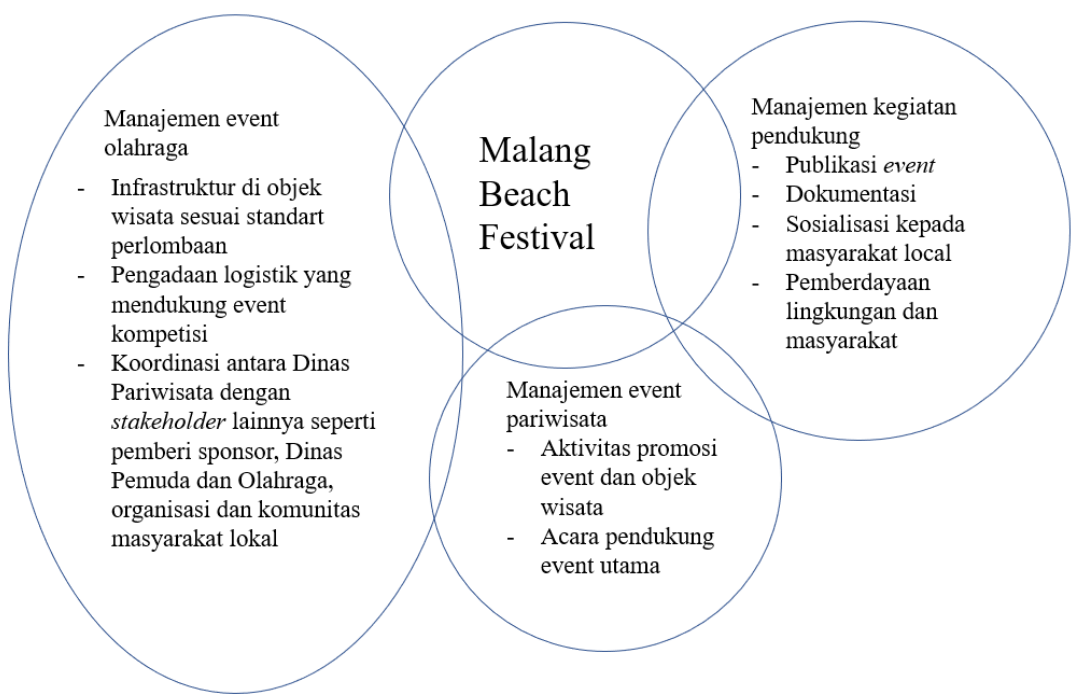

Sumber data: Data Penelitian, 2020

Menurut Kepala Dinas Pariwisata dan Kebudayaan Kabupaten Malang Made Arya Wedanthara, pada penyelenggaraan Malang Beach Festival II ada peningkatan dalam hal jenis kompetisi dan juga target peserta, misalnya dengan adanya Surfing International Competition di Pantai Nganteb yang diikuti kurang lebih 30 peserta yang terbagi tiga kategori, yakni Malang Raya, Jawa Timur, dan internasional (Nana 2019). Dari sisi 
manajemen kegiatan pendukung ada beberapa aktivitas termasuk didalamnya kegiatan promosi dan iklan destinasi wisata pantai yang termasuk juga promosi event.

Berdasarkan paparan yang disampaikan informan kunci dari Dinas Pariwisata dan Kebudayaan Kabupaten Malang, konsep sport tourism sudah menjadi salah satu trend gaya hidup, sehingga konsep sport tourism dipakai sebagai penyegaran strategi promosi untuk menarik wisatawan agar tidak hanya berkunjung untuk menikmati pemandangan pantai tetapi juga terlibat dalam aktifitas olahraga yang dikemas dalam bentuk sport event. Dalam perspektif pengembangan destinasi wisata, pelaksanaan kegiatan sport tourism dapat memberikan dampak pada usaha promosi dan pengenalan daerah tujuan wisata di daerah tersebut (Masjhoer 2016). Usaha promosi destinasi wisata sport tourism dilakukan dengan menggunakan saluran komunikasi event, kemudian untuk mengenalkan event tersebut kepada khalayak saluran komunikasi yang digunakan merupakan saluran komunikasi berupa iklan, public relations, dan worth of mouth marketing yang mana ketiga saluran komunikasi tersebut menggunakan media konvensional. Pemilihan saluran komunikasi melalui iklan dinilai masih cukup efektif untuk menimbulkan kesadaran merk (brand awareness) terhadap satu obyek wisata, sehingga Dinas Pariwisata dan Kebudayaan Kabupaten Malang tetap memberikan anggaran untuk beriklan di media nasional dan lokal pada setiap event yang menjadi agenda tahunan pariwisata. Kemudian saluran komunikasi berupa public relations tetap dilakukan dengan terus membina hubungan dengan berbagai stakeholder, seperti kerjasama antara Dinas Pariwisata dan Kebudayaan Kabupaten Malang dengan beberapa media di Singapura dan Malaysia untuk meliput berbagai obyek wisata pantai di Malang, selain kerjasama dalam hal liputan untuk kepentingan iklan dan promosi. Adanya kerjasama dalam hal promosi diakui oleh Kepala Seksi Promosi dan Kerjasama Pariwisata Kabupaten Malang membawa dampak meningkatnya jumlah kunjungan wisata dari kedua negara tersebut.

Dalam strategi komunikasi pemasaran, pemilihan saluran komunikasi dengan public relations dan worth of mouth marketing dapat berjalan secara beriringan, artinya jika fungsi public relations berjalan dengan baik, maka secara otomatis publik dan media akan mendengar dan menyebarkan informasi terkait suatu destinasi wisata. Hal ini sesuai dengan teori relationship management yang menjelaskan fungsi dasar public relations 
yaitu aktivitas komunikasi yang menghubungkan organisasi dan publik (Kriyantono 2014). Berdasarkan penjelasan yang diberikan oleh informan terkait pemilihan public relations sebagai salah satu model komunikasi pemasaran untuk mengenalkan konsep sport tourism, maka relationship management antara otoritas pengelola objek wisata dengan berbagai pihak harus dapat saling berkontribusi dan kolaborasi.

\section{Gambar 3. Model Komunikasi Pemasaran Sport Tourism dengan Saluran Public \\ Relations dan Iklan}

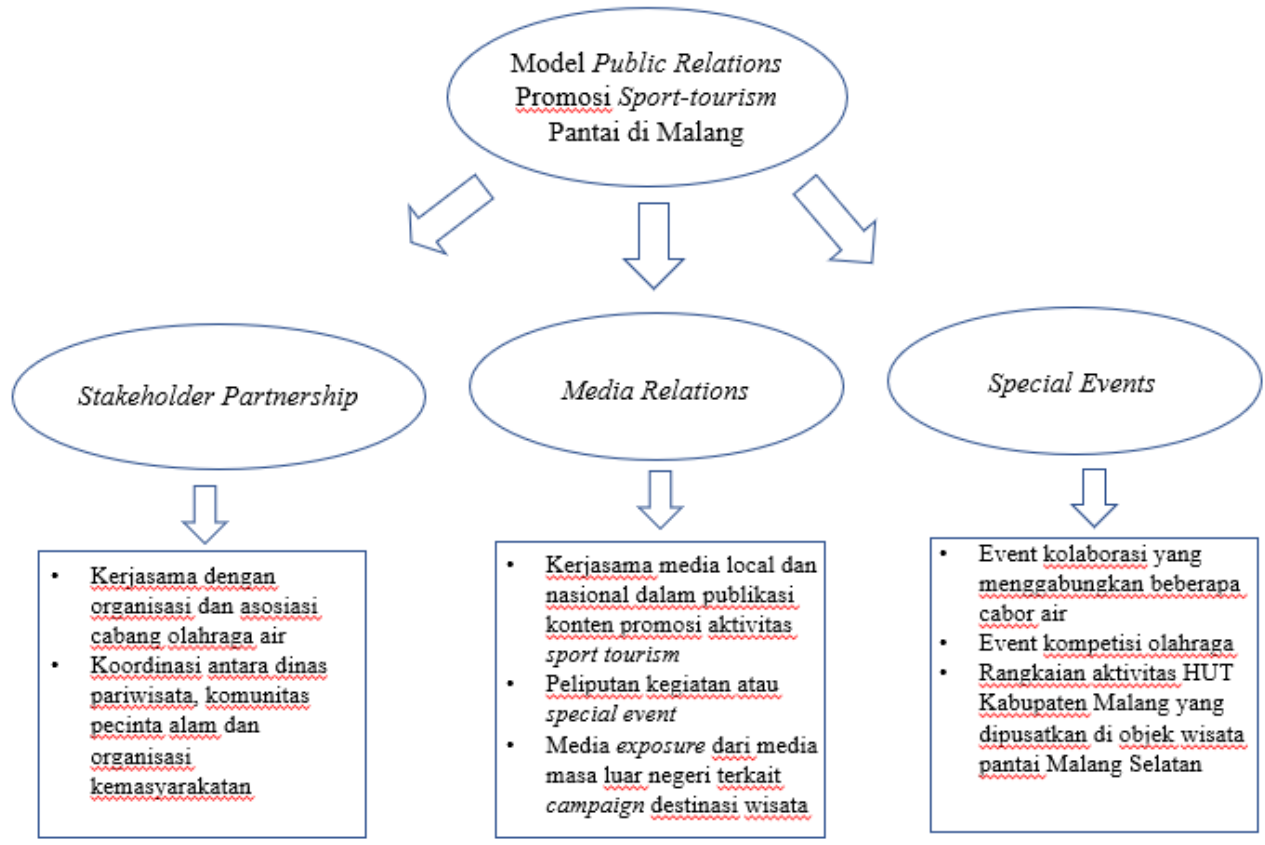

Sumber data: Data penelitian, 2020

Berbagai penjelasan yang diberikan oleh informan kunci dari dinas pariwisata dan kebudayaan, menunjukkan bahwa sebenarnya strategi promosi yang dilakukan Dinas Pariwisata dan Kebudayaan Kabupaten Malang cukup menyeluruh. Walaupun masih ada beberapa taktik promosi yang masih diusahakan dapat tereksekusi, yaitu memasukkan wisata Kabupaten Malang sebagai lokasi pengambilan gambar atau latar setting film. Tidak hanya film pendek tetapi juga layar lebar, karena kalangan milenial saat ini dekat dengan media baru promosi, dan juga ada nilai tambah. Saat lokasi menjadi angle pengambilan gambar atau setting film layar-lebar, muncul kesempatan luas yang bukan hanya sekedar brand awareness dari lokasi wisata tetapi juga brand image measurement yang baik membuat Pariwisata Kabupaten Malang. 
Berdasarkan Pokdarwis Pantai Lenggoksono, Pokdarwis Pantai Ngudel dan masyarakat sekitar sepakat bahwa strategi digital branding yang dilakukan di beberapa portal digital Dinas Pariwisata dan Kebudayaan mencakup seluruh kegiatan pariwisata di Malang Raya, sehingga promosi mengenai Pantai Malang Selatan masih minor atau tidak menjadi fokus utama. Selain itu problem terkait konten pada akun resmi Dinas Pariwisata dan Kebudayaan Kabupaten Malang yang dianggap kurang familiar menurut beberapa informan (pengunjung objek wisata). Saluran komunikasi antara tokoh masyarakat dan penggiat wisata merupakan pola komunikasi yang masih bersifat person to person belum terlembagakan (Bakti et al., 2018). Hal tersebut juga masih terjadi di pantai Ngudel dan sekitarnya, seperti yang disampaikan oleh salah satu anggota Pokdarwis sehingga promosi wisata pantai setempat belum terkoordinasi dengan otoritas pengelola pantai. Adanya persoalan terkait konten promosi pantai di Malang Selatan melalui digital platform yang sulit diakses, menunjukan bahwa kebutuhan masyarakat atau calon wisatawan akan akses informasi tentang pantai-pantai yang akan dikunjungi.

Dari problem keterbatasan konten promosi wisata, dapat disimpulkan bahwa konsep sport tourism belum secara jelas terintegrasi dalam strategi promosi destinasi wisata melalui media digital, sehingga salah satu model komunikasi pemasaran yang dirancang adalah membangun konten promosi berupa pembuatan dokumentasi event wisata olahraga yang telah diselenggarakan di beberapa pantai seperti event Malang Beach Festival, Malang Beach Run dan beberapa kegiatan sport tourism lainnya dalam bentuk video kreatif. Selain pembuatan video kreatif yang nantinya dapat dimuat dalam media digital dinas pariwisata dan kebudayaan kabupaten Malang. Selain melalui pembuatan video kreatif tentang kegiatan wisata olahraga, konsep sport tourism juga dapat diperkuat melalui dokumenter yang mengambil latar belakang pantai dengan menunjukan excitement masyarakat lokal ketika menjadi bagian dari penyelenggaraan event. Gambar 4 adalah skema model komunikasi pemasaran melalui media digital berdasarkan persoalan yang dihadapi oleh dinas pariwisata dan kebudayaan terkait konten promosi yang tepat. 


\section{Gambar 4. Model Komunikasi Pemasaran Terpadu melalui Media Digital}

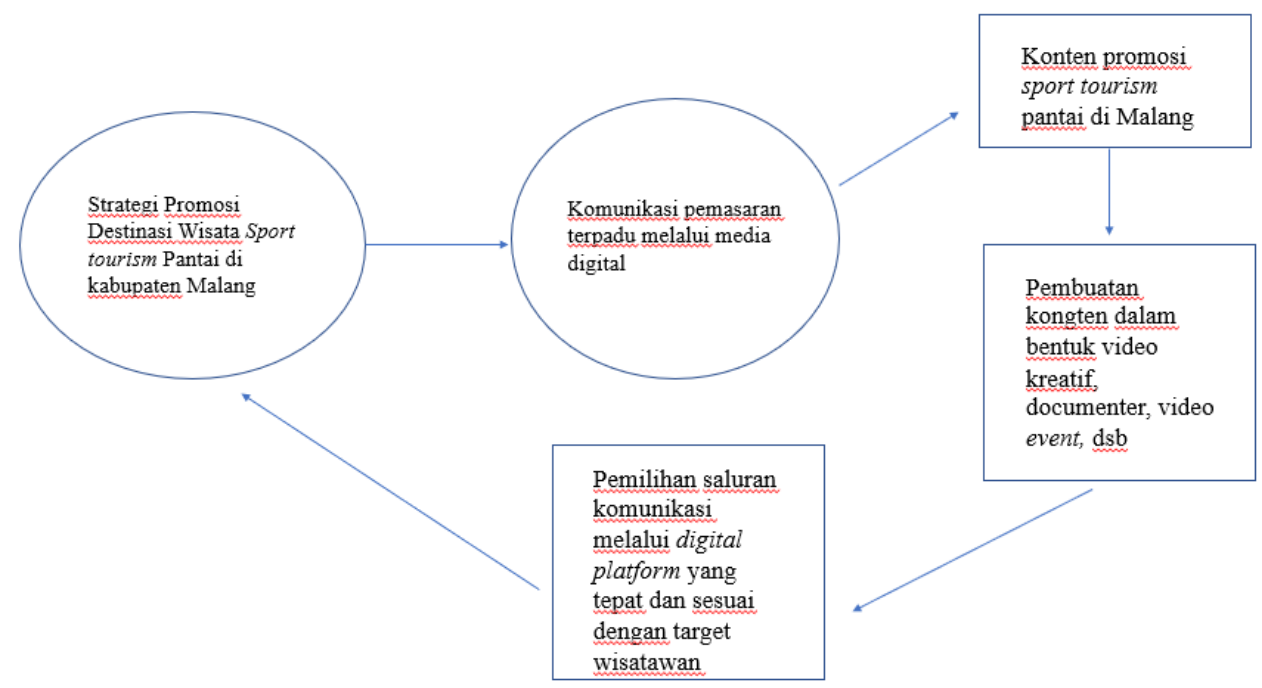

Sumber data: Data Penelitian, 2020

Dalam model komunikasi tersebut, dapat dijelaskan bahwa saluran komunikasi berupa media digital menjadi salah satu media yang tepat dalam menyampaikan pesan tentang konsep sport tourism yang diangkat sebagai brand image wisata pantai di Malang. Menurut kepala Bidang Pemasaran dan Pengembangan Wisata, menyampaikan bahwa wisatawan yang berkunjung ke pantai di Malang paling banyak dari kelompok usia remaja sampai dengan dewasa yang mana mereka mendapatkan informasi tentang objek pantai melalui akses internet. Bahkan wisatawan dari mancanegara juga mengakses informasi saat akan mengunjungi pantai di Malang adalah melalui internet.

Penggunaan akses internet untuk memperoleh informasi, menggiring wisatawan pada digital platform yang menyajikan konten informasi berupa, foto, gambar, artikel dan video. Menurut Arnott (2002), digital platform dapat menciptakan interaksi yang potensial dengan pelanggan pada skala global, selain itu adanya kemungkinan interaksi ditangkap oleh pemasar sebagai target pelanggan mereka pada basis one-to-one dan membangun brand loyalty relationships (Arnott \& Bridgewater, 2002). Interaksi dengan pelanggan secara digital tersebut diharapkan dapat meningkatkan kinerja pemasaran, sehingga strategi interaktif dibutuhkan jika menggunakan saluran komunikasi melalui media digital. Berdasarkan hasil pengamatan dan wawancara, ditemukan bahwa 
strategi interaktif dalam saluran komunikasi new media yang digunakan oleh Dinas Pariwisata dan Kebudayaan Kabupaten Malang belum menunjukan intensitas yang tinggi. Intensitas interaksi perlu dilakukan untuk meningkatkan brand engagement, sehingga aktivitas promosi melalui media digital termasuk campaign promosi yang dibuat mampu menciptakan rasa kagum dan penasaran untuk mengunjungi suatu destinasi. Untuk meningkatkan intensitas interaksi dalam model komunikasi pemasaran dengan saluran media digital, pemilihan platform yang tepat menjadi hal yang utama. instagram sebagai platform digital utama yang menjadi pusat informasi untuk promosi destinasi wisata Kabupaten Malang. Instagram dipilih karena merupakan salah satu platform digital yang paling populer di dunia, serta sifatnya yang sangat visual dan mudah diakses sehingga dapat menunjang promosi pariwisata Kabupaten Malang. Platform digital instagram ini kemudian akan terhubung dengan website, dimana website ini berisi informasi lengkap tentang destinasi wisata yang berada di bawah naungan Kabupaten Malang. Di dalam website ini juga berisi informasi mengenai platform digital lainnya yang mempromosikan pariwisata Kabupaten Malang, seperti youtube. Dalam platform youtube, konten-konten dengan karakter audiovisual seperti video documenter, infografis, video event, dan sebagainya dipublikasikan.

\section{KESIMPULAN}

Sport tourism sebagai konsep yang dapat dikembangkan sebagai strategi destinasi branding objek wisata pantai di Kabupaten Malang tepat, karena melihat potensi beberapa pantai di kabupaten Malang yang memiliki karakteristik ideal digunakan sebagai jantung wisata bahari karena sifatnya one stop tourism. Dengan sifatnya yang one stop tourism, maka dibutuhkan model komunikasi pemasaran sebagai salah satu strategi untuk mengenalkan dan meningkatkan brand engagement destinasi wisata sport tourism yang memunculkan pengalaman kepada calon pengunjung destinasi wisata pantai di Malang. Dalam pemilihan model komunikasi untuk mendukung branding yang tepat diperlukan saluran komunikasi yang terintegrasi, dan mampu memberikan brand experience yang baik sehingga meningkatkan engagement bagi wisatawan maupun calon wisatawan. 
Model komunikasi yang terbentuk dalam pengembangan destinasi wisata sport tourism pantai di Malang menggunakan pendekatan public relations sebagai strategi penguatan hubungan dan kerjasama antara pengelola destinasi wisata dengan organisasi, public, dan media sebagai stakeholder. Dengan pendekatan public relations yang berjalan, maka secara otomatis publik dan media akan mendengar dan menyebarkan informasi terkait suatu destinasi wisata. Bentuk aktivitas yang dapat dilakukan dengan public relations diantaranya seperti stakeholder partnership, media relations, dan special events. Dari pendekatan public relations akan menghasilkan luaran berupa aktivitas yang mendukung branding sport tourism, sehingga secara tidak langsung meningkatkan dari brand awareness sampai brand image measurement yang tinggi.

Model komunikasi dengan pendekatan media digital merupakan salah satu saluran komunikasi yang paling mudah diakses oleh calon wisatawan untuk memperoleh informasi dengan up date dan dengan berbagai jenis konten. Dengan beberapa digital platform juga memunculkan adanya interaksi yang potensial dengan pelanggan pada skala global. Interaksi dengan pelanggan secara digital tersebut diharapkan dapat meningkatkan kinerja pemasaran, sehingga strategi interaktif dibutuhkan jika menggunakan saluran komunikasi melalui media digital. Untuk meningkatkan intensitas interaksi dalam model komunikasi pemasaran dengan saluran media digital, platform yang tepat seperti Instagram dan youtube mampu mendukung campaign promosi yang mampu menciptakan rasa kagum dan penasaran untuk mengunjungi suatu destinasi. Bentuk integrasi komunikasi pemasaran melalui media digital dapat dilakukan dengan menghubungkan website resmi pengelola destinasi wisata dengan beberapa digital platform tersebut, sehingga strategi komunikasi pemasaran dengan beberapa saluran komunikasi media digital akan memiliki konsep yang teratur dan konsisten sesuai dengan branding destinasi yang ditetapkan.

\section{DAFTAR PUSTAKA}

Amazia, Domasti. Auzi. 2019. Mengenal "Sport Tourism" yang Semakin Populer. May 15. https:/ /lifestyle.kompas.com/read/2019/05/15/181900720/mengenal-sporttourism-yang-semakin-populer-. 
Arnott, D. C., \& Bridgewater, S. (2002). Internet, interaction and implications for marketing. Marketing Intelligence $\mathcal{E}$ Planning. https://doi.org/10.1108/02634500210418509

Bakti, I., Sumartias, S., Damayanti, T., \& Nugraha, A. R. (2018). Pengembangan Model Komunikasi Pariwisata Berbasis Kearifan Lokal di Kawasan Geopark Pangandaran. Jurnal Kajian Komunikasi, 6(2), 217. https://doi.org/10.24198/jkk.v6i2.18459

Bungin, Burhan. 2015. Komunikasi Pariwisata (Tourism dan Communication) : Pemasaran dan Brand Destinasi . Jakarta: Prenada Media.

Court, B., \& Lupton, R. A. (1997). Customer portfolio development: Modeling destination adopters, inactives, and rejecters. Journal of Travel Research. https://doi.org/10.1177/004728759703600106

Gumilang, Binar. 2019. Malang Beach Festival, Pantai Modangan Jadi Venue Kejuaraan Paralayang TROI Seri ke-4. November 21. https://www.timesindonesia.co.id/read/news/240180/malang-beach-festivalpantai-modangan-jadi-venue-kejuaraan-paralayang-troi-seri-ke4.

Kotler, Philip, and Gary Armstrong. 2017. Principles of Marketing. 17. London: Pearson Educated Limited.

Kriyantono, Rahmat. 2014. Teori-Teori Public Relations Perspektif Barat E Lokal: Aplikasi Penelitian dan Praktik. 2. Jakarta: Kencana.

Masjhoer, Jussac Maulana. 2016. "Implementasi Pemanfaatan Sport Tourism dalam Pemanfaatan Potensi Sungai di Indonesia; Studi Kasus International Musi Triboatton 2015." Jurnal Online Mahasiswa Bidang Ilmu Sosial dan Ilmu Politik 6.

Moilanen, T., \& Rainisto, S. (2009). How to Brand Nations, Cities and Destinations. In How to Brand Nations, Cities and Destinations. https:/ / doi.org/10.1057/9780230584594

Nana, Dede. 2019. Menengok Jejak Belia Malang Beach Festival Kabupaten Malang. May 5. https://www.malangtimes.com/baca/39032/20190505/132000/menengokjejak-belia-malang-beach-festival-kabupaten-malang. 
EXPOSE: Jurnal Ilmu Komunikasi

ISSN 2620-8105 | E-ISSN 2621-0304

Volume 03, No. 01, April, 2020

Nur Mufidatunnisa, Dewi Susilowati, Djamang Ludiro. 2014. "Pola Keruangan Tipologi Objek Wisata di Kabupaten Malang." FMIPA UI 9.

Pandu, Yesi. 2018. Pentingnya Menciptakan Brand yang Kuat di Suatu Destinasi Pariwisata. January 25. https:/ / pemasaranpariwisata.com/2018/01/25/brand-destinasi/.

Risitano, M. (2006). The role of destination branding in the tourism stakeholders system. The Campi Flegrei case. IV International Doctoral Tourism and Leisure Colloquium.

Saputra, Heldi, and Syafri Harto. 2016. "Dampak Pelaksaaan Event Internasional Sail Indonesia Terhadap Perkembangan Wisata Bahari Indonesia." Jurnal Online Mahasiswa (JOM) Bidang Ilmu Sosial dan Ilmu Politik 315.

Siregar, Syofian. 2013. Metode Penelitian Kuantitatif dan Kualitatif. Jakarta: Fajar Interpratama Mandiri. 